\title{
Study on Determinant Factors of Micro and Small Enterprises Development in South Sulawesi of Indonesia
}

\author{
Musran Munizu \\ Faculty of Economics and Business, Hasanuddin University, Indonesia \\ JIn. Perintis Kemerdekaan KM. 10, Tamalanrea, Makassar 90245 \\ Email:m3.feunhas@gmail.com \\ Sumardi \\ Faculty of Economics and Business, Hasanuddin University, Indonesia \\ JIn. Perintis Kemerdekaan KM. 10, Tamalanrea, Makassar 90245 \\ Email: sumardi.feunhas@gmail.com \\ Armayah \\ Faculty of Economics and Business, Hasanuddin University, Indonesia \\ Jln. Perintis Kemerdekaan KM. 10, Tamalanrea, Makassar 90245 \\ Email: armayah.feunhas@gmail.com
}

Doi:10.5901/mjss.2016.v7n6p121

\section{Abstract}

The purposes of this study is to examine factors determinants of development of micro and small enterprises in South Sulawesi, Indonesia. This research was conducted in two regions namely, Makassar and Gowa. Total respondents are 150 people, and 10 people as key informants. Data is analyzed by using Descriptive Statistic, Structural Equation Modeling, and Analytical Hierarchy Process (AHP). The results show that the development of micro and small businesses should consider the internal aspects namely human resources, finance, production, and marketing. Then, the external aspects namely government policies, socio-economic and cultural, the role of related institutions, and information technology. Development strategy is more focused on internal capacity improvement than external. Furthermore, the other factors that determine the performance of Micro and Small business are capital, training, market information, marketing network, promotional of products, and institutional capacity.

Keywords: determinant factors, development, micro and small business, business performance

\section{Introduction}

SMEs has an important and strategic role in the economy of Indonesia. In 2011 SMEs contribute 61.9 percent of revenue on gross domestic product (GDP) through the payment of taxes. In 2012 the number of business units has reached 56.5 million units and total workforce of about 107.7 million people. The number of SMEs is very large compared to other businesses that is 98.8 percent of business units that accommodate 92.8 percent of the workforce in Indonesia (Ministry of Cooperative and SMEs, 2013).

According to Stel and Zoetermeer (2004), the role of SMEs can be said to be very important in the national economy. Its role especially in the aspects of increasing employment opportunities, increasing income and rural economic development, and an increasing in non-oil exports. SMEs able to alleviate poverty through employment creation and contribution to GDP. Besides its important role, SMEs also experienced a variety of problems, dealing specifically with its performance.

The existence of SMEs is undoubted because it proved able to survive and become an economy wheel driver, especially after the economic crisis. On the other hand, SMEs also face a lot of problems, namely the lack of working capital, low human resources, and lack of utilization of science and technology (Sudaryanto and Hanim, 2002). Another problem SMEs is related to business prospects that are less obvious as well as planning, and also the vision and mission that have not been sharp. This happens because SMEs are family business owned, using simple technology, lack of 
access to capital, and employers sometimes don't perform separation between private need and the need of business capital.

Study on the performance of SMEs is conducted by Wilkinson (2002) states that the Micro and Small Enterprises (MSEs) can be grown if supported by an external environment factor conductively such as pro-business policies and the macro environment is stable, and predictable. Then, the availability of for easily accessible information, as well as the social environment. Furthermore, Maupa (2004) found the individual characteristics of the manager / owner, the characteristics of the company, the external environment of business, and the impact of economic and social policies have a direct effect, positive and significant to business strategy and business growth. Then, characteristics of the company and the impact of social and economic policies have a direct effect, and negatively on business strategy, but the strategy of business have a direct effect, positive and significant on the company's growth.

Furthermore, the same study was conducted by Research Center of Hasanuddin University which is identified six things constitute primary barriers of SMEs entrepreneurs in managing their business. If ordered from the highest to the lowest are Capital (58.0\%), equipment of production (24.0\%), location cost $(12.0 \%)$, price fluctuations $(2,7 \%)$, raw materials (2.0\%), and position location (1.3\%) (LP-UNHAS, 2006). The other study was conducted by Munizu (2010) found that external factors consisting of aspects of government policy, socio-cultural and economic, and the aspect of the role of related institutions have a positive influence on internal factors with a contribution 0.980 or $98 \%$. Then, the external factors which consists of aspects of government policy, socio-cultural and economic aspects, and aspects of role of related institutions have a positive influence on performance of micro and small business with a contribution 0.792 or $72.9 \%$ and internal factors have a positive influence on performance of micro and small enterprises with a contribution 0.254 or $25.4 \%$.

Tambunan (2010) asserted that SMEs have a very important role in the Indonesian economy. Acceleration of capacity building of SMEs through capital assistance should be done to improve its ability in taking advantage of business opportunities which is created by economic growth, trade, and investment. In addition, SMEs have to optimize the support of other factors that determine the growth of their performance. It is very important for SMEs, especially in the facing of higher competition, improving its role in creating jobs, reducing poverty, and deals with the implementation of the ASEAN Economic Community in 2015. Related to the Development of Micro and Small Enterprises (MSES), Hadiyati (2010) identified the weaknesses and problems faced by SMEs based on priorities, the which include: (a) the lack of capital (b) Difficulties in marketing, (c) the tight competition, (d) the difficulty of raw materials, (e) the lack of technical skills of production, (f) the lack of managerial skills, and $(\mathrm{g})$ lack of knowledge in management issues.

Bouazza et al. (2015) found the critical factors that determine the growth of SMEs in Algeria, namely factors of the business external environment which were beyond control, and internal factors. External factors include the legal and regulatory aspects, access to sources of finance, and human resource capacity improvement. Internal factors more emphasis on entrepreneurial character, capacity management, marketing capabilities, and technological capacity. Then, Kinyua (2014) found that access to financial institutions have significant effect to performance of SMEs as well as macroeconomic environment, while the infrastructure factor is not significant effect on the performance. Granting lowinterest loan scheme which could be help businesses to improve their business performance.

Based on both phenomenon and empirical facts which is stated above, the purpose of the study was to identify factors that determine the performance of Micro and Small Enterprises, to test and to analyze the effect of these factors on performance of Micro and Small Enterprises, and to determine the priority factors in the development Micro and Small Enterprises as well as the strategy in developing Micro and Small Enterprises in South Sulawesi, Indonesia.

\section{Literature Review}

\subsection{Concept of Micro and Small Enterprises}

Definition of micro, small and medium enterprises could be seen from several aspects. In Indonesia's economy, small and medium enterprise sector plays an important role, especially when linked to the amount of labor that can be absorbed by SMEs. Besides having a strategic role for development, SMEs also serve as a means to distribute evenly results of the development that have been achieved.

Tambunan (2010) asserts there are some definitions of micro and small enterprises. Bank Indonesia defines a small business is a business that has total assets of Rp 60 million not including land or occupied homes. BPS using the approach of classifying the amount of labor in the business, namely: (a) Enterprises Households have 1-5 workers, (b) Small businesses have 6-19 workers, (c) medium businesses have 20- 99 labor, and (d) large businesses have more than 100 workers. Furthermore, micro-enterprises according to Decree of the Minister of Finance Number 40 / KMK.06 / 
2003 is a family-owned productive enterprises or individuals with the sale of a maximum of Rp 100 million per year, and the number of proposed credit maximum of Rp 50 million

Based on Law No. 20 of 2008 on Micro, Small, and Medium Enterprises that Microenterprise is a productive enterprise belonging to individuals and / or entities that meet the criteria of individual enterprise namely: (a) has a net asset fifty million, including land and buildings; or (2) has an annual sales turnover of three hundred million rupiah. Whereas small enterprise is an economic enterprise productive that stands alone, conducted by an individual or business entity that is not a subsidiary or not a branch of the company owned, controlled, or be a part either directly or indirectly from medium or large businesses that meet the criteria namely: (a) has a net asset more than fifty million rupiahs up to at most five hundred million rupiah not including land and buildings; or (b) has an annual sales turnover more than three hundred million rupiahs up to at most two billion five hundred million rupiahs.

\subsection{The Problems for Small and Micro Enterprise Development}

According to Jafar (2004) the development of Micro, Small, and Medium Enterprises (SMEs) is essentially a shared responsibility between the government and the public. Some of the problems associated with the development of SMEs are: (1) The creation of a business climate conducive, (2) Assistance to capital from the government, (3) Protection of business, (4) the Partnership, (5) Training, (6) Institutions, (7) Market.

Related to the empowerment of micro and small enterprises, Haeruman (2000) noted that the challenges of development covers several broad aspects, i.e.: (1) improving the quality of human resources in terms of management skills, organization and production technology, (2) competence of entrepreneurship, (3) greater access to capital, (4) asymmetric market information, (5) other factors of production inputs, and (6) business climate that encourages innovation, entrepreneurship and business practices and fair competition. According to Rizal (2002), the constraints commonly faced by micro, small and medium enterprises include low productivity, less value-added products, small investment, limited market area, business networks extremely limited, lack of access to sources of capital and raw material, and unprofessional management.

Setyobudi (2007) divides the problems of SMEs in three categories i.e.: (1) basic problem consist of the problem of limited capital, the legal status of which is generally non-formal, human resources, product development and market access, (2) intermediate problems such as financial management, collateral, and limitations in entrepreneurship, and (3) advanced problems associated with the introduction of advanced and export market penetration is not optimal, lack of understanding of the design of products that fit the needs of the market, legal issues concerning patents, sales contract procedures, and regulations in destination countries.

Based on the problems existing SMEs, the principle of empowerment of Micro, Small and Medium accordance with Law No. 20 of 2008 directed at a few things: (1) growing the independence, unity, and entrepreneurial of micro, small and medium enterprises to work with their own initiatives; (2) manifestation of public policy which are transparent, accountable and equitable; (3) business development based on local potential and market-oriented in accordance with the competence of Micro, small and medium enterprises; (4) increasing the competitiveness of micro, small and medium enterprises; and, (5) conducting of the planning, implementation and control in an integrated manner. Then the goal the empowerment of Micro, Small and Medium Enterprises namely: (1) achieving a balanced structure of the national economy, developing, and justice; (2) growing and developing the ability of Micro, Small and Medium enterprises into a strong and independent, and (3) enhancing the role of micro, small and medium enterprises in regional development, job creation, income generation, economic growth and poverty alleviation.

\subsection{Business Performance}

Business performance is the level of attainment or achievement of the company within a certain time period. Hansen and Mowen (2005) distinguishes measure of performance both traditional and contemporary. Traditional performance is measured by comparing the actual performance with the performance of budgeted or standard costs in accordance with the characteristics of responsibility, whereas the contemporary performance is measured by activities as its foundation.

The performance measure is designed to assess how well the activities carried out and can to identify whether it has made continuous improvements. Munizu (2010) and Munizu et al. (2015) measures the performance of SMEs by using five (5) indicators, namely: sales growth, profit growth, employment growth, market growth, and growth of capital. 


\section{Research Methodology}

The study was conducted in Province of South Sulawesi, which were in Makassar City and Gowa District. Selection of sample districts based on the consideration that the district is the center of micro and small enterprises are the biggest in South Sulawesi. The population of this research is all Micro and Small Enterprises (MSEs) are listed on the Department of Cooperatives and SMEs in Makassar, and Gowa. According to data released by the BPS, the number of MSEs in Makassar in 2014 is 43,550 units, whereas in Gowa is 18,700 units. So that the number of units in the population of both areas is 62,250 units.

Determinations about the number of samples which represents the population is processed by using the formula of Slovin (Umar, 2010). The reason for using this formula is to obtain a representative sample amount. The formulation as follows:

$$
n=\frac{N}{1+N(e)^{2}}
$$

Noted:

$\mathrm{n}=$ total of sample

$\mathrm{N}=$ total of population

e $=$ Precision rate 10\%, confidence interval at $90 \%$

According to formula, the sample size of the study as follow:

$n=\frac{62.250}{1+62.250(10 \%)^{2}}=93$ it could be 100 (minimum sample)

Based on the calculation above, the sample size minimum was 100 persons. At the end of data collection, there were 150 persons which have participated in the study. Furthermore, focus group discussion (FGD) is conducted with 10 key informants selected from stakeholders include government, employers, universities, NGOs, and associations.

Research variables were divided into three variables which consist of external factors, internal factors, and business performance. The main tool for data collection was questionnaire. Before of data collection, the questionnaire has to test its validity and reliability. Furthermore, method of analysis is used in the study were (1) Descriptive statistic, (2) Structural Equation Modeling (Hair et al., 2011) and, (3) Analytical Hierarchy Processes (Saaty, 2008; Mulyono, 2012). Thus, data was analyzed by using IBM SPSS and AMOS and Expert Choice 9.5

\section{Results and Discussion}

\subsection{Results of Validity and Reliability Test}

Testing the validity and reliability of the instrument is essential before data collection. Results of testing the validity and reliability could be presented in the following table.

Table 1. Results of Validity and Reliability Test

\begin{tabular}{|c|c|c|c|c|}
\hline \multicolumn{2}{|c|}{ No. Variables/ Indicators } & Correlation Coefficient & Cronbach Alpha & Explanation \\
\hline \multicolumn{5}{|c|}{ I. Internal factors } \\
\hline \multirow[t]{4}{*}{ a. } & Human Resource & & \multirow{4}{*}{0.792} & Reliable \\
\hline & - $\quad H R 1$ & 0.5763 & & Valid \\
\hline & HR2 & 0.6342 & & Valid \\
\hline & HR3 & 0.5446 & & Valid \\
\hline \multicolumn{4}{|c|}{ b. Financial } & Reliable \\
\hline & FL1 & 0.5000 & \multirow{3}{*}{0.880} & Valid \\
\hline & FL2 & 0.6372 & & Valid \\
\hline & FL3 & 0.4945 & & Valid \\
\hline \multicolumn{3}{|c|}{ c. Operation and Technical } & \multirow{4}{*}{0.882} & Reliable \\
\hline & OT1 & 0.4912 & & Valid \\
\hline & OT2 & 0.6776 & & Valid \\
\hline & OT3 & 0.6263 & & Valid \\
\hline \multicolumn{4}{|c|}{ d. Marketing } & Reliable \\
\hline & MG1 & 0.6618 & \multirow{3}{*}{0.776} & Valid \\
\hline & MG2 & 0.7328 & & Valid \\
\hline & MG3 & 0.7313 & & Valid \\
\hline
\end{tabular}




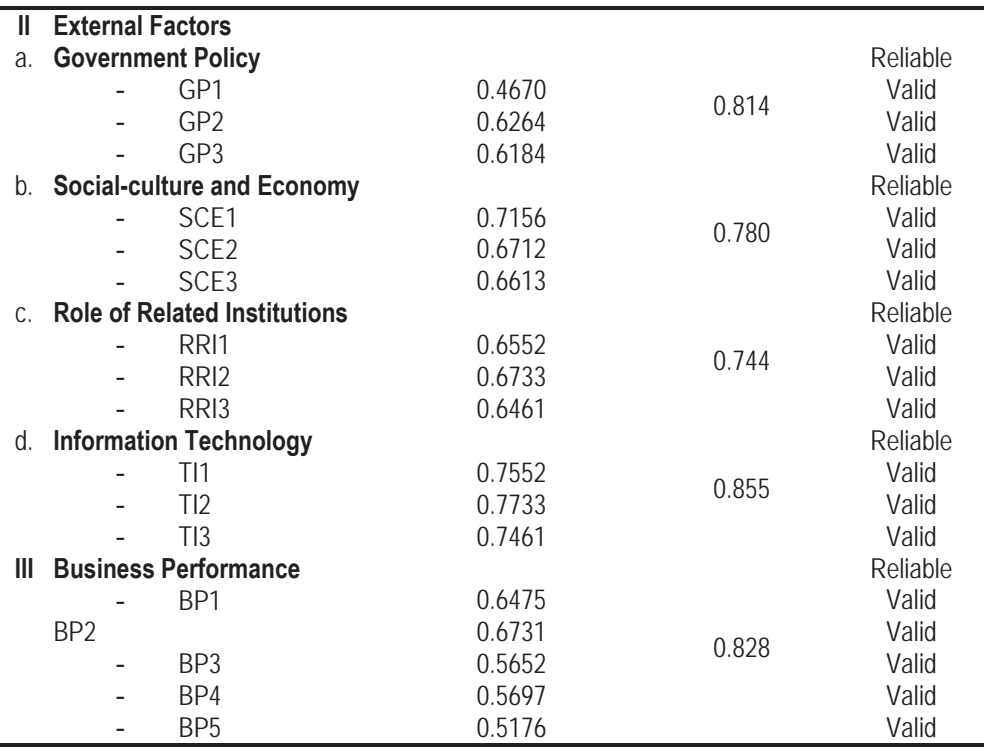

Source: Data processed, 2015

Based on the table, it can be known that (1) the value of correlation on all indicators is greater than $0.30(r>0.30)$, so it could be concluded that indicators which used to measure the variables of the study were valid, (2) Instruments is used in data collection have a high level of reliability. It could be seen from the value of Cronbach's alpha (a) of each variable that greater than the standard value $(\alpha>0.60)$.

\subsection{Descriptive of Respondents}

Result of descriptive analysis showed that the participants are dominant by male sex (74.7\%) and women (25.3\%). Most of the respondents come from areas that traditionally considered to have a strong trading culture namely Makassar tribe (52\%) and Bugis tribe (33.3\%). The rest comes from a mixture of Makassar Bugis, Javanese, Palu, Manado, Dayak, and Sunda.

The education level of respondents was dominant at high school level (60\%), the rest was at the level of Bachelor I S1 (13.3\%), SD and SMP each one (9.3\%) and Diploma (8\%). Then in terms of age, respondents of the study were dominant in the productive age categories, namely $31-40$ years (41.3\%) and $41-50$ years (28\%), the rest were in the age of $20-30$ years $(18.7 \%)$, aged $50-60$ years $(10.7 \%)$ and 60 years $(1.3 \%)$. Furthermore, was also known that respondents have generally long enough in business by business experience for 5-10 years (57.3\%) and 11-20 years (25.3\%), while the rest was respondent below 5 years (10.7\%), 21-30 years (4\%) and 31-40 years (2.7\%).

\subsection{Hypothesis Testing}

Research hypothesis testing using SEM analysis. Based on the results of the calculation of the value of goodness-of-fit indices (GFI) on the complete model that describes the relationship between the variables presented in the following table.

Table 2. Results of Testing Goodness of fit indices Overall Model

\begin{tabular}{lccc}
\hline Criteria & Cut-off Value & Results & Explanation \\
\hline Chi-Square & Expected small value & 15.160 & Good \\
CMIN/DF & $\leq 2.00$ & 1.225 & Good \\
GFI & $\geq 0.90$ & 0.957 & Good \\
RMSEA & $\leq 0.08$ & 0.085 & Good Enough \\
CFI & $\geq 0.95$ & 0.955 & Good \\
TLI & $\geq 0.95$ & 0.968 & Good \\
\hline
\end{tabular}

Source: Data processed, 2015 
The test results of the conformance criteria structural model, shows the model is good, so it could be used to estimate and to analyze the results of the research. After the model accepted, the subsequent analysis was to analyze the value of loading factor and probability of each variables in the study. The complete results of hypothesis testing could be presented in the following table.

Table 3. Research Hypothesis Testing Results

\begin{tabular}{|c|c|c|c|c|c|}
\hline Relationship Among Variables & Intervening Variable & Path Coefficient & Critical Ratio & Sig. & Explanation \\
\hline \multicolumn{6}{|l|}{ Direct Effect } \\
\hline External Factors $\rightarrow$ Internal Factors & - & 0.640 & 6.950 & 0.000 & $\begin{array}{l}\text { Significant } \\
\text { (H1, accepted) }\end{array}$ \\
\hline Internal Factors $\rightarrow$ Business Performance & - & 0.454 & 4.472 & 0.005 & $\begin{array}{l}\text { Significant } \\
\text { (H2, accepted) }\end{array}$ \\
\hline External Factors $\rightarrow$ Business Performance & - & 0.288 & 2.760 & 0.021 & $\begin{array}{l}\text { Significant } \\
\text { (H3, accepted) }\end{array}$ \\
\hline \multicolumn{6}{|l|}{ Indirect Effect } \\
\hline External Factors $\rightarrow$ Business Performance & Internal Factors & \multicolumn{3}{|c|}{$0,640 \times 0,454=0,291$} & $\begin{array}{l}\text { Significant } \\
\text { (H4, accepted) }\end{array}$ \\
\hline
\end{tabular}

Source: Data processed, 2015

Then, complete model which could explain the causal relationship between variables in the study could be presented in Figure below.

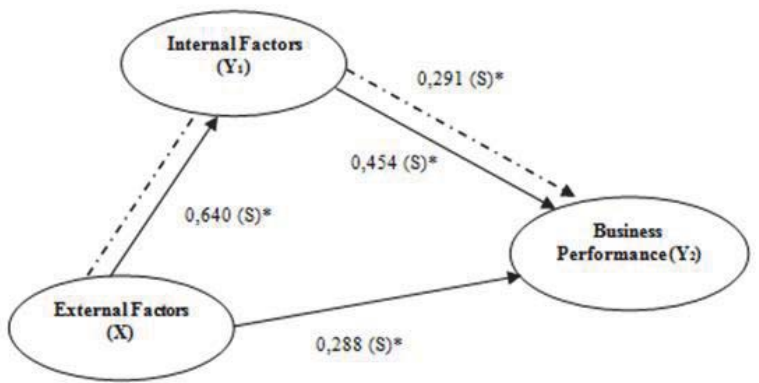

Notes : *) Relationship among variables, significant at ( $a \leq 0.05)$

Figure 1. Results of Research Model

Based on table, it could be concluded that external factors have a positive and significant effect to internal factors. These findings consistent with Temtime and (2004), Maupa (2004), Munizu (2010), Hadiyati, (2010), Kinyua (2014), and Munizu et al. (2015) that internal capacity improvement of micro and small business in the human resources aspects, financial aspects, technical aspects of production / operations, and aspects of information technology should be supported by governments, stakeholders, socioeconomic and cultural environment and information technology. The table also shows that internal factors have a positive and significant effect to business performance of micro and small enterprises. These findings support some research previously such as Munizu (2010), Yaghoobi et al. (2010), Pinho and DeSa (2014), Halabi and Lussier (2014), and Kinyua (2014) that performance of micro and small business could be increased when it is supported by improvement of resources internal.

In addition, the study also found that external factors have a positive and significant effect to business performance of micro and small enterprises. The results of this study indicate that the better government policies, socio-cultural support, best support from universities, NGOs, private sector, and the support of information technology could lead to improvements in the performance of Micro and small in South Sulawesi. Better business performance was indicated by sales growth, capital growth, employees growth, market share growth, and operating income improvement (Maupa, 2004; Munizu 2010; Hadiyati 2010; Pinho and DeSa, 2014; Halabi and Lussier, 2014; and Munizu et al., 2015). Furthermore, external factors could improve the business performance through internal factors. Business performance can be determined by external factors directly, or indirectly through improving the capacity of the organization's internal 
resources. Bouazza et al. (2015) confirms the internal factors more emphasis on entrepreneurial character, capacity management, marketing capabilities, and technological capacity, while external factors related to the external environment of business.

\subsection{Analysis of Priority Factors for Strategic Formulation}

Based on the analysis of AHP, priority factors which determines micro and small enterprises performance in South Sulawesi can be presented in the following table.

Table 4. Weights and Criteria of determinants the performance of Micro and Small Enterprises

\begin{tabular}{clcc}
\hline No. & Factors & Weights & Priority \\
\hline 1. & Human resource aspect & 0.114 & 5 \\
2. & Finance aspect & 0.120 & 4 \\
3. & Technical and operation aspect & 0.158 & 2 \\
4. & Marketing aspect & 0.184 & 1 \\
5. & Government policy & 0.102 & 6 \\
6. & Socio-culture and economy & 0.088 & 8 \\
7. & Role of related institutions & 0.142 & 3 \\
8. & Information technology & 0.092 & 7 \\
\hline
\end{tabular}

Source: Data processed, 2015

The table describes that criteria or factors of marketing has the highest weighting $(0.184)$, then followed by the technical aspects of production and operations (0.158), and aspects of the role of related institutions (0.142). Marketing aspect related to marketing areas, and the ease of distributing the product to consumer. Furthermore, technical aspects related to quality control activities and product quality assurance. Creating attractive package, hygienic products, product durable, and quality assurance certification (SNI), and ISO 9001: 2008. Then, priorities strategy in the development of alternative strategies in developing micro and small enterprises in South Sulawesi could be presented at the following table.

Table 5. Weights Value and Alternative Strategies for Developing of Micro and Small Enterprise

\begin{tabular}{clcc}
\hline No. & Alternative Strategy & Weights & Priority \\
\hline 1. & Internal capacity improvement & 0.648 & 1 \\
2. & External capacity improvement & 0.352 & 2 \\
\hline
\end{tabular}

Source: Data processed, 2015

The table above shows that development of Micro and Small Enterprises should be focused on internal capacity improvement strategy which consist of human resources, financial, technical production and operations, aspects of the market and marketing aspect rather than external capacity improvement. In addition to the improvement of internal capacity, other factors that determine the performance of Micro and Small Enterprises are: (1) the capital assistance, (2) the creation of conducive business climate, (3) training / technical guidance/ coaching, (4) market information and marketing network, (5) socialization and promotional products, (6) institutional strengthening.

\section{Conclusion}

The better the government support in policies, social-cultural and economic support, the role of related institutions such as universities, NGOs, private sector, and other relevant institutions and the support of adequate information technology could lead to improvement of internal condition and performance of Micro and Small Enterprises on Human resources aspects, financial aspects, technical aspects of production and operations, and marketing aspects. Micro and small enterprises should be consistent in improving business performance through some activities which focused on effort to improve of internal elements and external that determine the growth of micro and SMEs performance which consist of market share, capital, labor, income / profit, and sales in order fit to the business goal. 


\section{References}

Bouazza, Asma Benzazoua, Diabate Ardjouman, Othman Abada. (2015). Establishing the Factors Affecting the Growth of Small and Medium-sized Enterprises in Algeria, American International Journal of Social Science, 4(2): 101-15

Department of Cooperatives and SMEs in South Sulawesi province. (2006). Formulation of Development Micro Business in South Sulawesi, Hasanuddin University Research Center - Department of Cooperatives and SMEs SulSel Press.

Hadiyati, E. (2010). Marketing for SMEs: Theory and Applications, Malang: Bayumedia Press.

Haeruman, H. (2000). Improvement of SME Competitiveness Support Program for PEL. Competitiveness Improvement Seminar Papers, Jakarta: Graha Sucofindo

Hair, Joseph F. Jr., Ralph E. Anderson and Ronald L. Thatam. (2011). Multivariate Data Analysis, New Jersey, USA: Prentice-Hall inc.

Halabi, Claudia E. and Robert N. Lussier. (2014). A model for predicting small firm Performance Increasing the probability of entrepreneurial success in Chile, Journal of Small Business and Enterprise Development, 21 (1): 4-25

Hansen, Don R. and Maryanne Mowen. 2005. Cost Management: Accounting and Control, Jakarta: Salemba Empat Press.

Jafar, Muhammad. (2004). An effort of Development of Small and Medium Enterprises (SMEs), Infokop Bulletin, 25 (XX): $22-30$.

Kinyua, Anne Ngima. (2014). Factors Affecting the Performance of Small and Medium Enterprises in the Jua Kali Sector In Nakuru Town, Kenya, IOSR Journal of Business and Management (IOSR-JBM) 16 (1): 80-93

Mallarangeng, Rizal. (2002). Breaking the Economic centralism, Jakarta: Gramedia Pustaka Utama Press

Maupa, Haris. (2004). Factors Determining Growth of Small and Medium Enterprises (SMEs) in South Sulawesi. Dissertation, Hasanuddin University, Unpublished.

Mulyono, Sri. (2012). Decison Making Theory, Jakarta: FEUI Press.

Munizu, Musran, Sumardi, Armayah. (2015). Studies on Determinants of Performance Micro and Small Enterprises and its Role in Reducing Poverty in South Sulawesi, Unpublished, Self Report, Makassar: Hasanuddin University

Munizu, Musran. (2010). The influence of External Factors and Internal factors to Performance of Micro and Small Enterprises (MSEs) in South Sulawesi, Management and Entrepreneurship Journal, 12: 33-41.

Pinho, Jose Carlos and Elisabete Sampaio DeSa. (2014). Personal characteristics, business relationships and entrepreneurial performance: Some empirical evidence, Journal of Small Business and Enterprise Development, 21(2): 284-300

Saaty, T.L. (2008). How to make a decision: the analytic hierarchy process, Interfaces, Vol. 24 (6): 19-43

Setyobudi, Andang. (2007). Participation of central bank in the Development of Micro, Small and Medium Enterprises (SMEs), Bulletin of Banking Law and Central Bank, 5 (1): 29-35

Statistik UMKM. (2013). Annual Report of State Ministry of SMEs and Cooperatives, Jakarta: UMKM Press

Stel, Carree, Thurik Zoetermeer. (2004). The Effect of Entrepreneurship on National Economic Growth: an Analysis Using the GEM Database. SCALES Paper No. 320: 11-20

Sudaryanto dan Hanim, Anifatul. (2002). Evaluate the readiness of SMEs Toward the Asean Free Trade Area (AFTA): Analysis of Perspectives and Theoretical Perspectives. Economics, Accounting, and Management Journal, 1 (2): 11-20

Tambunan, Tulus. (2010). Small and Medium Enterprises in Indonesia, Some Key Issues, Jakarta: Salemba Empat Press.

The Act No. 20 Year 2008 on Micro, Small and Medium Enterprises (SMEs), Jakarta: Ministry of Cooperative and SME Publisher.

The Central Bureau of Statistics Gowa. (2014). Gowa in Figures, Sungguminasa: BPS Press

The Central Bureau of Statistics Makassar. (2014). Makassar in Figures, Makassar: BPS Press

Umar, Husain. (2010). Human Resources Research in Organization, Jakarta: Gramedia Pustaka Utama Press.

Wilkinson, B. (2002). Small, Micro, and Medium Enterprise Development : Expanding the Option for Debt and Equity Finance. Financial Sector Workshop, National Economic Development and Labour Council (NEDLAC), Johanesburg, South Africa, Iris, April 6, 2002

Yaghoobi, Salarzehi, Aramesh and Akbari. (2010). An Evaluation of Independent Entrepreneurship Obstacles in Industrial SMEs, European Journal of Social Sciences,(12): 33-45 